\title{
JOURNAL.RU
}

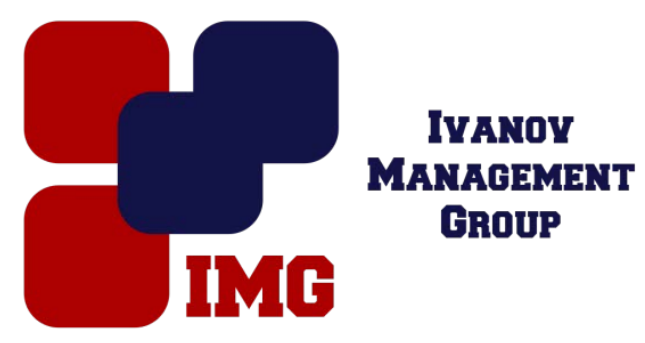

Богданова О.В., Лузина Ю.Л., Филатова Ю.Д. Донской Государственный Технический Университет Ростов-на-Дону, Россия

doi: 10.18411/lj-28-02-2017-3-07

idsp 000001:lj-28-02-2017-3-07

\section{Эксплуатируемая крыша как способ формирования общественного пространства}

Общественные пространства - это такая часть городской среды, которая доступна для населения. Чаще всего под общественными пространствами понимаются места, где происходит общение людей, протекает их общественная жизнь. К таким пространствам относят: площади, набережные, улицы, пешеходные зоны, парки, детские площадки. Можно сказать, что именно общественные пространства формируют единую городскую среду, контекст, реализуя возможность для совместного проведения досуга, общения, реализации творческих идей и т.д.

Общественные пространства условно можно разделить на несколько категорий:

- социально-событийные - площади, набережные и т.п.;

- культурно-досуговые - театры, кинотеатры и открытые пространства рядом с ними (которые также могут быть задействованы);

- зеленые рекреационные - парки и скверы;

- политические - такие, как Гайд-парк;

- обыденные - дворы, придомовые детские площадки;

- спортивные - спортивные площадки и комплексы;

- отдыха - кафе, рестораны и др.

Для общественных пространств требуются достаточно большие территории, что является проблемой в современном мире, так как плотность городской застройки увеличивается с каждым годом.

Много способов для решения этой проблемы было предложено архитекторами. Один из них - организация общественных пространств на крышах зданий.

Сначала самым популярным способом было использовать крышу здания как 
небольшой сад, куда люди могли бы ходить отдыхать, любуясь раскинувшимися вокруг городскими панорамами и зеленой растительностью. Подобные объекты можно найти по всему миру. Но со временем, на крыше стали появляться общественные пространства и с другими функциями.

На основе анализа были выявлены такие интересные объекты как: отель Marina Bay Sands в Сингапуре, где огромная пальмовая роща переходит в бассейн у самого края двухсотметрового обрыва, а в Лондоне на крыше торгового центра Selfridges расположен другой водный объект, не имеющий никакого отношения к бассейну для плавания (там обустроена сеть каналов, по которым можно передвигаться на небольших лодочках, рассчитанных на двух человек), футбольное поле на крыше небоскреба в Токио (благодаря системе искусственного освещения, этот спортивный объект на крыше работает круглосуточно), парк аттракционов на крыше небоскреба Stratosphere в Лас-Вегасе для людей, которые не боятся высоты (ведь кружиться на карусели и других аттракционах посетителям этого парка предстоит, зависая на высоте 250 метров над уровнем земли - именно на этой отметке находится крыша небоскреба Stratosphere), теннисный корт на крыше знаменитого отеля-паруса Burj Al Arab в Дубае (на высоте 211 метров над уровнем моря), кинотеатр на крыше жилого дома в Мельбруне.

Таким образом, внедрение эксплуатируемых крыш в структуру зданий, стало эффективным способом формирования общественных пространств. Такой способ, позволяет не только сэкономить земельные территории, но и создать комфортные, уникальные общественные пространства для общения и отдыха людей.

\section{Литература}

1. Малахов, С.А. Принципы предварительной теории архитектурного объекта / С.А. Малахов // Приволжский научный журнал, № 2, Периодическое научное издание. - Н. Новгород, ННГАСУ, 2013. - С. 68.

2. Пространство, время, архитектура. Зигфрид Гидион. 1998

3. История архитектуры./Огюст Шуази. - Издательство В. Шевчук, 2009. 